\title{
NILAI-NILAI PENDIDIKAN KARAKTER DALAM NOVEL IBUK KARYA IWAN SETYAWAN
}

\author{
Cintya Nurika Irma \\ Program Studi Pendidikan Bahasa dan Sastra Indonesia, FKIP, Universitas Peradaban \\ Jalan Ray a Pagojengan Km. 3, Paguy angan, Brebes, Jawa Tengah \\ surel: cintya_nurikairma@y ahoo.co.id
}

Informasi Artikel:

Dikirim: 5 Januari 2018; Direvisi: 1 Februari 2018; Diterima: 4 Februari 2018

DOI: $10.26858 /$ retorika.v11i1.4888

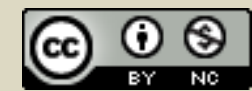

RETORIKA: Jurnal Bahasa, Sastra dan Pengajarannya berada di bawah lisensi Creative Commons Attribution-NonCommercial 4.0 International License.

ISSN: 2614-2716 (cetak), ISSN: 2301-4768 (daring) http://ojs.unm.ac.id/retorika

\begin{abstract}
Values of Character Education in Novel Ibuk Karya Iwan Setiawan. This study aims to describe the values of character education contained in Novel Ibuk by Iwan Setyawan. Research is designed with qualitative approach. Data were collected by using the method of reading and record and analyzed descriptive qualitative. The results showed that there were 12 values of character education in Ibuk novels, including (1) simple living, (2) responsibility, (3) affection, (4) filial piety, (5) religious, (6) caring, (7) appreciating achievement, (8) hard work, (9) love homeland, (10) honest, (11) empathy, and (12) like to read. Based on these findings, Novel Ibuk deserves to be used as teaching materials for literature in high school because it contains many educational values.
\end{abstract}

\begin{abstract}
Abstrak: Nilai-nilai Pendidikan Karakter dalam Novel Ibuk Karya Iwan Setiawan. Penelitian ini bertujuan mendeskripsikan nilai-nilai pendidikan karakter yang terdapat dalam Novel $I b u k$ karya Iwan Setyawan. Penelitian didesain dengan pendekatan kualitatif. Data dikumpulkan dengan menggunakan metode baca dan catat dan dianalisis deskriptif kualitatif. Hasil penelitian menunjukkan bahwa terdapat 12 nilai-nilai pendidikan karakter dalam novel Ibuk, meliputi (1) hidup sederhana, (2) tanggung jawab, (3) kasih sayang, (4) berbakti pada orang tua, (5) religius, (6) peduli, (7) menghargai prestasi, (8) kerja keras, (9) cinta tanah air, (10) jujur, (11) empati, dan (12) gemar membaca. Berdasarkan temuan itu, Novel Ibuk layak dijadikan sebagai bahan ajar pembelajaran sastra di sekolah menengah karena mengandung banyak nilai pendidikan.
\end{abstract}

Kata kunci: karakter, Ibuk, nilai pendidikan, novel 
Dalam karya sastra, pengarang berusaha menggambarkan segala peristiwa yang dialami masyarakat dalam kehidupan sehari-hari. Karya sastra juga tidak terlepas dari rekaman peristiwaperistiwa kebudayaan di dalam hidup manusia. Sastra dan kebudayaan memiliki objek yang sama, yaitu manusia dan masyarakat, manusia sebagai fakta sosial dan manusia sebagai makhluk kultural (Ratna, 2004:14). Hasil realitas sosial menunjukkan karya sastra berakar pada kultur tertentu di dalam lingkungan masyarakat. Keberadaan sastra yang demikian menjadikan ia dapat diposisikan sebagai dokumen sosiobudaya.

Karya sastra menerima pengaruh dari masyarakat dan sekaligus mampu memberi pengaruh terhadap masyarakat, salah satunya adalah novel. Sudjiman (1998:53) mengatakan bahwa novel adalah prosa rekaan yang menyuguhkan tokoh dan menampilkan serangkaian peristiwa serta latar secara tersusun. Novel sebagai karya imajinatif mengungkapkan aspek-aspek kemanusiaan yang mendalam dan menyajikannya secara halus. Novel tidak hanya sebagai alat hiburan, tetapi juga sebagai bentuk seni yang mempelajari dan meneliti segi-segi kehidupan dan nilai-nilai baik buruk/moral dalam kehidupan dan mengarahkan pada pembaca tentang budi pekerti yang luhur.

Dalam rangka lebih memperkuat pelaksanaan pendidikan karakter pada satuan pendidikan, telah ditetapkan 18 nilai-nilai pembentuk karakter bangsa yang bersumber dari agama, pancasila, budaya, dan tujuan pendidikan nasional (Kemendiknas, 2010:9). Selanjutnya, Mansur (2014:6-7) menambahkan penjelesan lebih rinci terkait 18 nilai tersebut. Pertama, religius adalah sikap dan perilaku yang patuh dalam melaksanakan ajaran agama yang dianutnya, toleran terhadap pelaksanaan ibadah agama lain dan hidup rukun dengan pemeluk agama lain. Kedua, jujur adalah perilaku yang didasarkan pada upaya menjadikan dirinya sebagai orang yang selalu dapat dipercaya dalam perkataan, tindakan, dan pekerjaan. Ketiga, toleransi adalah sikap dan tindakan yang menghargai perbedaan agama, suku, etnis, pendapat, sikap, dan tindakan orang lain yang berbeda dari dirinya. Keempat, disiplin adalah tindakan yang menunjukkan perilaku tertib dan patuh pada berbagai ketentuan dan peraturan.

Kelima, kerja keras adalah perilaku yang menunjukkan upaya sungguh-sungguh dalam mengatasi berbagai hambatan belajar dan tugas, serta menyelesaikan tugas dengan sebaik-baiknya. Keenam, kreatif adalah berpikir dan melakukan sesuatu untuk menghasilkan cara atau ha- sil baru dari sesuatu yang telah dimiliki. Ketujuh, mandiri adalah sikap dan perilaku yang tidak mudah tergantung pada orang lain dalam menyelesaikan tugas-tugas. Kedelapan, demokratis, adalah cara berpikir, bersikap, dan bertindak yang menilai sama hak dan kewajiban dirinya dan orang lain. Kesembilan, rasa ingin tahu, adalah sikap dan tindakan yang selalu berupaya untuk mengetahui lebih mendalam dan meluas dari sesuatu yang dipelajarinya, dilihat, dan didengar.

Kesepuluh, semangat kebangsaan, adalah cara berpikir, bertindak, dan berwawasan yang menempatkan kepentingan bangsa dan negara di atas kepentingan diri dan kelompoknya. Kesebelas, cinta tanah air, adalah cara berpikir, bersikap, dan berbuat yang menunjukkan kesetiaan, kepedulian, dan penghargaan yang tinggi terhadap bahasa, lingkungan fisik, sosial, budaya, ekonomi, dan politik bangsa. Kedua belas, menghargai prestasi adalah sikap dan tindakan yang mendorong dirinya untuk menghasilkan sesuatu yang berguna bagi masyarakat, dan mengakui, serta menghormati keberhasilan orang lain. Ketiga belas, komunikatif adalah tindakan yang memperlihakan rasa senang berbicara, bergaul, dan bekerja sama dengan orang lain. Keempat belas, cinta damai adalah sikap, perkataan, dan tindakan yang menyebabkan orang lain merasa senang dan aman atas kehadiran dirinya.

Kelimabelas, gemar membaca adalah kebiasaan menyediakan waktu untuk membaca berbagai bacaan yang memberikan kebajikan bagi dirinya. Keenambelas, peduli lingkungan adalah sikap dan tindakan yang selalu berupaya mencegah kerusakan pada lingkungan alam di sekitarnya, dan mengembangkan upaya-upaya untuk memperbaiki kerusakan alam yang sudah terjadi. Ketujuhbelas, peduli sosial adalah sikap dan tindakan yang selalu ingin memberi bantuan pada orang lain dan masyarakat yang membutuhkan. Kedelapanbelas, tanggung jawab adalah sikap dan perilaku seseorang untuk melaksanakan tugas dan kewajibannya, yang seharusnya dia lakukan, terhadap diri sendiri, masyarakat, lingkungan (alam, sosial dan budaya), negara dan Tuhan Yang Maha Esa.

Armis, dkk. (2015) menyimpulkan dalam penelitiannya yang berjudul "Representasi Tokoh Lisa dalam Novel Bunda Lisa Karya Jombang Santani Khairen: Kajian Psikologi Wanita" bahwa peranan tokoh Lisa meliputi peranan wanita sebagai istri, peranan wanita sebagai ibu dan pendidik, peranan wanita sebagai mahluk sosial yang berpartisipasi aktif dalam masyarakat. So- 
sok ibu yang dianggap sebagai pengemudi dalam rumah tangga. Hal ini juga terikat akan kondisi sebagian perempuan yang masih dibatasi untuk keluar dari zonanya. Kampanye dalam lingkup emansipasi pun merasuk pada berbagai karya sastra. Beberapa gejolak tersebut muncul sebagai reaksi pertentangan agama, budaya, sosial, politik maupun ekonomi.

Berbeda dengan Armis, dkk., Hayati (2014) dalam penelitiannya yang berjudul "Representasi Ibu dalam Sastra Anak di Indonesia (Studi Kasus terhadap Sastra Anak Karya Anak Periode 2000-an)" menggambarkan peran feminin yang melekat pada diri perempuan mengharuskan dia untuk selalu berada di rumah untuk menjadi ibu rumah tangga sehingga dunia domestik adalah dunia yang dimiliki oleh perempuan. Dalam sastra anak digambarkan ibu-ibu yang mandiri dan mampu mengambil keputusan sendiri tanpa harus menunggu keputusan suami. Hal itu terlihat dari tokoh-tokoh perempuan (ibu) yang mempunyai hak yang sama dengan ayah dalam mengambil keputusan, tokoh-tokoh perempuan dalam sastra anak tersebut masih mempunyai kemampuan terbatas yang terlihat dari aktivitas publik tokoh perempuan yang ma-sih berkaitan erat dengan dunia domestiknya yai-tu memasak dan mengasuh (menjadi guru).

Penggambaran ibu dalam penelitian sastra yang telah dipaparkan merupakan bagian dari refleksi penulis. Djajanegara (2003:19) bahwa wanita memiliki perasaan-perasaan yang sangat pribadi, seperti penderitaan, kekecewaan, atau rasa tidak aman yang hanya bisa diungkapkan secara tepat oleh wanita itu sendiri. Misalnya, bagaimana seorang laki-laki mampu menulis secara rinci rasa sakit, cemas, serta bahagia seorang perempuan menjelang di waktu dan setelah melahirkan bayi? Pengarang perempuan akan lebih mengena atau menyentuh ketika menggambarkan karakter tokoh perempuan tersebut. Karena secara tidak langsung biasanya ia menggambarkan karakter tokoh perempuan tersebut berdasarkan apa yang penulis rasakan sendiri. Sementara pengarang laki-laki, menggambarkan karakter tokoh perempuan berdasarkan apa yang pernah dilihatnya dari perempuan-perempuan yang pernah dikenalinya. Akan tetapi, tidak menutup kemungkinan pengarang laki-laki akan lebih pandai dalam menggambarkan tokoh perempuan karena keliaran imajinasinya. Oleh karena itu, perspektif dan pengalaman penulis menjadi bagian penting dari karyanya, termasuk novel Ibuk yang menjadi kajian dalam penelitian ini.
Dalam karya sastra akan tersimpan nilai atau pesan yang berisi amanat atau nasihat. Melalui karyanya, pencipta karya sastra berusaha untuk memengaruhi pola pikir pembaca dan ikut mengkaji tentang baik dan buruk, benar mengambil pelajaran, teladan yang patut ditiru sebaliknya, untuk dicela bagi yang tidak baik. Karya sastra diciptakan bukan sekadar untuk dinikmati, akan tetapi untuk dipahami dan diambil manfaatnya (Setiadi, 2006:110). Selanjutnya, Pradopo (2005:30) menambahkan bahwa novel merupakan salah satu bentuk karya sastra yang banyak memberikan penjelasan secara jelas tentang sistem nilai. Nilai itu mengungkapkan perbuatan apa yang dipuji dan dicela, pandangan hidup yang dianut dan dijauhi, dan hal apa saja yang dijunjung tinggi.

Salah satu karya sastra yang memuat nilainilai pendidikan adalah novel Sabtu Bersama Bapak Karya Adhitya Mulya. Hasil analisis Soharahab dan Marwati (2016) terkait novel tersebut disimpulkan bahwa terdapat tiga nilai pendidikan, yaitu 1) nilai pendidikan religius, 2) nilai pendidikan moral, 3) nilai pendidikan sosial. Selain itu, Novel Sabtu Bersama Bapak relevansi dengan Pembelajaran Bahasa Indonesia berdasarkan kurikulum 2013 pada kompetensi inti KI 1 dan KI 2 tentang menghargai dan menghayati ajaran agama yang dianutnya dan menghargai dan menghayati perilaku jujur, disiplin, tanggung jawab, peduli (toleransi, gotong royong), santun, percaya diri, dalam berinteraksi secara efektif dengan lingkungan sosial dan alam dalam jangkauan pergaulan dan keberadaannya maka hasil penelitian ini relevan untuk pembelajaran di sekolah.

Karya sastra tak terlepas dengan korelasi dengan masyarakat. Oleh sebab itu, kajian yang dapat digunakan adalah melalui sosiologi sastra. Endraswara (2008) mengemukakan bila sosiologi sastra adalah cabang penelitian sastra yang bersifat reflektif. Penelitian ini banyak diminati oleh peneliti yang ingin melihat sastra sebagai cermin kehidupan masyarakat. Arenanya, asumsi dasar penelitian sosiologi sastra adalah kelahiran sastra tidak dalam kekosongan sosial. Berdasarkan uraian latar belakang masalah tersebut, tujuan penelitian ini adalah mendeskripsikan nilai-nilai pendidikan karakter yang terdapat dalam Novel Ibuk karya Iwan Setyawan.

\section{METODE}

Subjek dalam penelitian ini adalah Novel Ibuk karya Iwan Setyawan yang diterbitkan Ben- 
tang Pustaka 2012, berisi 293 halaman. Metode penelitian yang digunakan dalam penelitian ini adalah metode deskriptif kualitatif. Keabsahan data dilakukan dengan triangulasi data dan teori. Selanjutnya, teknik analisis dilakukan dengan langkah-langkah (a) pengumpulan data dengan mengumpulkan bahan-bahan pustaka serta membaca berulang-ulang secara keseluruhan maupun sebagian novel Ibuk, (b) mengidentifikasi data berupa kalimat yang akan menjawab masalah penelitian, (c) mereduksi data dengan mencatat dilanjutkan mengklasifikasi data sesuai dengan permasalahan penelitian, (d) penyajian data berdasarkan hasil penelitian serta perumusan masalah, dan (e) penarikan simpulan. Selain itu, reduksi data selalu dilakukan bila simpulan dirasa kurang.

\section{HASIL DAN PEMBAHASAN}

Hasil

Berdasarkan hasil analisis terdapat dua belas nilai-nilai pendidikan yang ditemukan dalam Novel Ibuk karya Iwan Setyawan yang diuraikan sebagai berikut.

\section{Hidup Sederhana}

Pada novel Ibuk amanat hidup sederhana diperankan oleh tokoh Ibuk. Kehidupan perekonomian Ibuk yang terbilang pas-pasan, tetapi Ibuk berhasil mengatur segala kebutuhan rumah tangga dan sekolah anak-anaknya. Selain itu, Ibuk tetap bisa menabung seberapapun uang yang bisa ditabung dan tidak boros. Kebiasaan ini juga selalu diingatkan dan diterapkan kepada anak-anaknya mulai usia dini dan bila nanti bekerja dan memiliki penghasilan sendiri, menabung menjadi prioritas terutama untuk biaya kesehatan sebab dirasa sangat mahal bagi yang memiliki kemampuan ekonomi rendah. Menabung tidak selalu identik dengan bank, tempat penyimpanan tradisional, seperti menaruhnya ditumpukan baju dalam lemari dilakukan oleh ibu seperti dalam kutipan berikut ini.

(1) "Berapa pun uang yang kau miliki, jangan pernah berlebihan. Nabung! Kamu bisa jatuh sakit. Harus ke dokter dan itu tidak murah. Hidupmu tidak hanya untuk sekarang saja. Hidupmu masih panjang," pesan Ibuk yang tidak mempunyai rekening di bank. Ibuk selalu menabung di bawah tumpukan baju di lemari tua (hlm. 102).

Novel Ibuk mendidik mengajarkan nilainilai untuk hidup sederhana. Bagi kaum muda, hidup sederhana menjadi upaya untuk terhindar dari budaya konsumtif. Apabila pemahaman tersebut telah tertanam dan dibiasakan dimulai dari lingkungan keluarga tentu sikap boros dapat terhindar. Pola hidup konsumtif merupakan keinginan mengonsumsi barang-barang yang kurang diperlukan secara berlebihan hanya untuk mencari sisi kepuasan. Perilaku konsumtif memiliki banyak dampak negatif dibandingkan positifnya, dalam psikologi dikenal dengan sebutan compusive buying disorder (penyakit kecanduan belanja) sulit membedakan antara keinginan dan kebutuhan dan terjebak dalam dunia konsumeristik yang dibawa pasar kapitalisme. Perilaku konsumtif terjadi karena ingin tampak berbeda dengan ikut-ikutan hal tersebut yang menjadi dasar remaja berperilaku konsumtif. Dibutuhkan peran aktif orang tua agar remaja tidak menghamburhamburkan uang untuk hal-hal yang kurang penting (Assuari dalam Pangestu, 2014). Melalui novel ini, perilaku konsumtif dicegah melalui karakter tokoh yang mengajarkan pola hidup sederhana.

\section{Tanggung Jawab}

Latar belakang pendidikan bapak dan Ibuk membuat status ekonomi keluarga tidak dalam kategori cukup, tetapi mereka berjuang agar anak-anaknya dapat berpendidikan tinggi dan dapat memiliki pekerjaan serta kehidupan yang lebih baik dari orang tuanya. Inilah salah satu bentuk tanggung jawab Bapak dan Ibuk pada anakanaknya. Ibuk tidak segan-segan mengorbankan harta bendanya untuk pendidikan anak-anaknya seperti yang ditunjukkan pada kutipan berikut.

(2) "Iya kita jual angkot untuk kuliah ke Bogor," tegas Ibuk lagi menyakinkan Bayek. Semuanya masih diam, terkejut dengan kenekatan Ibuk (hlm. 133).

Kutipan data (2) menunjukkan Ibu agar anak-anaknya dapat sekolah sampai perguruan tinggi dengan menjual angkot yang menjadi sumber penghasilan Bapak. Novel ini menunjukkan tekad orang tua yang berusaha dan bekerja keras untuk memenuhi dan memberikan yang terbaik agar dapat menyekolahkan anaknya hingga perguruan tinggi. Tokoh Bapak dan Ibuk menjadi 
contoh bahwa harapan untuk mengubah kehidupan melalui keinginan menyekolahkan anak-anaknya hingga perguruan tinggi. Keinginan yang amat besar tersebut hingga pada masa krisis pendapatan keluarga, Bapak dan Ibuk merelakan angkot yang menjadi mata pencaharian Bapak demi anaknya tidak putus sekolah. Semangat yang ingin ditunjukkan oleh penulis adalah menempatkan tanggung jawab pada anak sebagai nilai terpenting bagi orang tua.

\section{Kasih Sayang}

Novel ini memberikan pesan bahwa mohon doa restu kepada orang tua hal penting tidak bisa diabaikan. Hal ini terlihat dalam novel ini. Anak-anak Ibuk tiada henti mohon doa Ibuk akhirnya selalu diberi kemudahan dan hasil yang terbaik selama perjalanan menuntut ilmu, bekerja hingga berkeluarga. Berikut ini gambaran dari pernyataan tersebut.

(3) Begitulah. Doa dan perjuangan Ibuk dan Bapak tidak pernah berhenti untuk anakanaknya. Semangat juang anak-anaknya juga selalu segar untuk menuntut ilmu di sekolah. Mereka melangkah bersama. Mereka memperkuat satu sama lain (hlm. 131).

Melalui novel ini, kasih Ibu sepanjang masa diperlihatkan oleh tokoh Ibuk. Meskipun anakanaknya telah dewasa, Ibuk tetap memberikan perhatian kepada anak-anaknya. Salah satunya dilakukan pada Bayek yang merantau untuk bekerja. Ibuk selalu mengingatkan anaknya untuk menjaga pola makan meskipun sibuk bekerja serta untuk selalu bersyukur dan tidak meninggalkan ibadah. Bayek merupakan bentuk keberhasilan perjuangan Bapak dan Ibuk. Namun, meskipun anaknya telah berhasil, tokoh Bapak tidak ingin merepotkannya, hal ini tampak pada Bapak yang tetap bekerja sebagai sopir angkot.

\section{Berbakti pada Orang Tua}

Sepatutnya anak berbakti kepada orang tua. Anak tidak akan pernah bisa membalas budi pada orang tua. Dapat membuat orang tua bangga adalah impian dari Bayek. Bayek bekerja keras dan hasil jerih payah yang diperoleh tidak lupa selalu dikirimkan untuk orang tua dan membantu kebutuhan adik-adiknya. Hal tersebut dilakukan untuk meringankan beban orang tuanya. Ia mencontoh orang tuanya, perjuangan Bapak dan
Ibuk yang telah mengantarkan Bayek untuk hidup lebih baik, dapat menuntut ilmu hingga perguruan tinggi dan memperoleh pekerjaan sesuai yang diharapkan. Bayek pun menunjukkan baktinya sebagai anak pada orang tua dengan berjanji untuk membahagiakannya seperti dalam kutipan berikut ini.

(4) Malu kalau aku tak bisa bekerja keras seperti Bapak. Malu kalau aku tidak bisa membahagiakan beliau kelak, janji Bayek untuk Bapaknya (hlm. 143).

Selanjutnya, perhatian Bayek juga ditunjukkan dengan tiap hari memberi kabar kepada orang tua dan saudaranya melalui telepon meskipun kesibukan dalam bekerja. Sebagian anak yang sibuk bekerja terkadang lalai untuk memberi kabar atau bertemu pada orang tuanya. Terlebih bagi mereka yang bekerja jauh dari kediaman orang tua tentu akan lebih jarang untuk berkomunikasi secara langsung. Inilah yang terkadang tidak disadari bahwa ada yang dipendam dari orang tua yaitu kerinduan. Tokoh Bayek dalam novel ini menjadi model bakti anak pada orang tua. Orang tua tidak berharap pemenuhan secara finansial yang diberikan oleh anaknya saat telah bekerja, tetapi wujud bakti meskipun hanya sekadar selalu memberi kabar.

\section{Religius}

Novel Ibuk mengajarkan untuk memperkuat ajaran agama dan pelaksanaannya. Seperti yang dilakukan oleh tokoh Ibuk pada Bayek mengingatkan untuk tidak lupa beribadah. Usia Bayek yang sudah dianggap dewasa tentu sudah dianggap paham mengenai tanggung jawabnya untuk melaksanakan perintah-Nya tetapi tokoh Ibuk memberikan gambaran lain bahwa hal tersebut sudah menjadi bagian tanggung jawabnya untuk selalu mengingatkan anak-anaknya untuk meningkatkan kedekatanya pada Allah serta menjalankan perintah dan menjauhi laranganNya. Berikut kutipan yang menunjukkan pernyataan tersebut.

(5) "Kamu jangan lupa sholat ya, Le, bersyukur", Ibuk selalu mengingatkan Bayek (hlm. 141).

Tidak banyak orang tua yang melakukan hal yang sama seperti tokoh Ibuk ketika anakanak telah dianggap berusia dewasa sehingga sudah tidak wajar bila masih diingatkan me- 
ngenai ajaran-ajaran agama yang telah ditanamkan saat usia dini di lingkungan keluarga dan sekolah seperti salat yang menjadi kewajiban sehari-hari. Kekhawatiran ini disebabkan rutinitas pekerjaan yang bisa membuat lupa waktu untuk salat meskipun sudah mendengar azan. Sekali lupa seterusnya bisa menjadi terbiasa. Tokoh Ibuk melakukan peranannya sebagai agen merealisasikan penanaman pendidikan religius bagi anak-anaknya. Nilai religius ini merupakan salah satu nilai penting dalam novel Ibuk.

\section{Peduli}

Menjaga kebersihan tercermin dari perilaku anak-anak Ibuk. Hal ini disebabkan Ibuk yang selalu memberikan contoh nyata tanpa menyuruh anak-anaknya melakukan hal yang sama. Peniruan secara nyata dimulai dari lingkungan keluarga inilah yang coba disampaikan oleh penulis bahwa kepedulian harus ditumbuhkan pada diri anak-anak, seperti yang dilakukan oleh Isa dan Nani lalu ditiru oleh Bayek sebab selalu menyaksikan secara langsung kebiasaan kakak-kakaknya. Wujud nilai peduli yang dilakukan Bayek terlihat pada kutipan di bawah ini.

(6) Ini sudah menjadi kebiasaan Bayek setiap pulang sekolah. Ia langsung menyapu rumah tamu, mengepel lantai, dan mengelap kaca jendela. Bayek tidak akan menyentuh makan siang sebelum semua terlihat bersih. Berkilau. Bayek meniru kebiasaan Isa dan Nani (hlm. 87).

Melalui novel Ibuk, pembiasaan menjaga kebersihan perlu ditanamkan mulai dari diri sendiri. Penulis menunjukkan bahwa lingkungan keluarga menjadi tonggak keberhasilan realisasi tindakan tersebut. Sebagian orang tua seakan menghindarkan penanaman pembiasaan tersebut, salah satunya disebabkan pemilikan asisten rumah tangga sehingga segala sesuatu urusan pekerjaan rumah telah dilakukannya. Akibatnya hingga usia remaja bahkan dewasa beberapa pekerajaan rumah tangga seperti menyapu, mengepel, memasak belum pernah dilakukannya. Tindakan yang dapat dilakukan adalah dengan pemberian contoh dan pemahaman pembagian tugas pekerjaan rumah oleh orang tua pada anaknya.

\section{Menghargai Prestasi}

Bapak menunjukkan sikap menghargai prestasi anak-anaknya saat menandatangani rapor anak-anaknya. Bapak mengungkapkan dengan wajah sumringah dan tutur kata yang membuat anak-anaknya bangga karena prestasi yang telah dicapainya. Terselip pula Bapak hampir meneteskan air mata dan menyelipkan doa sebab betapa bahagia memiliki anak-anak yang pintar. Salah satunya terlihat saat Bayek dengan bahagianya menyampaikan kepada Bapak bahwa ia ranking dua. Meskipun tak melihat hasilnya secara langsung dan hanya mengetahui dari Ibuk sebab rapor masih ditahan pihak sekolah karena belum melunasi biaya buku, Bapak memberikan balasan dengan tuturan "pinter, pinter!". Tuturan tersebut berdampak pada meningkatnya motivasi dan prestasi belajar Bayek.

(7) "Paaak... aku rangking loro!" teriak Bayek. "Pinter, pinter! Terus ranking yo, Le," kata Bapak (hlm. 64).

Sebagaimana kutipan (7), novel Ibuk mengajarkan nilai penghargaan kepada anak. Peningkatan minat dan prestasi belajar anak dapat tercapai bila terjadi dukungan timbal balik orang tua bukan hanya guru. Bukan hanya tuntutan pada anak agar dapat selalu berprestasi tetapi dukungan orang tua untuk ikut berperan dalam proses pencapaian tersebut. Tuturan-tuturan lembut dan menyenangkan disertai dengan korelasi nonverbal, seperti dengan mengacungkan kedua jempol tangan, senyum, anggukan kepala sebagai tanda rasa bangga atau kesenangan. Kesalahan yang sering terjadi bila anak tidak berprestasi tidak sesuai yang diharapkan sehingga dimarahi atau pemberian hukuman, tindakan tersebut harus dihindarkan ubah dengan pemberian motivasi, wujud kebanggaan, dan anggapan bahwa setiap anak memiliki kelebihan yang berbeda-beda.

\section{Kerja Keras}

Tokoh Bapak dan Ibuk memberikan contoh betapa suatu keinginan dapat tercapai salah satunya dengan kerja keras. Komitmen Ibuk digambarkan dengan tampilkan sukses dalam mengatur ekonomi keluarga. Penghasilan Bapak diatur dengan baik oleh Ibuk dalam memenuhi kebutuhan keluarganya. Usahanya berhasil memenuhi biaya sekolah anak-anaknya dan menabung untuk membeli angkot bekas. Tentu secara teori hal tersebut tidak mudah dilakukan dengan pendapatan Bapak yang tidak menentu. Pernyataan tersebut dapat dilihat pada kutipan data yang ditunjukkan di bawah ini. 
(8) Berkat kerja keras Bapak, keuletan Ibuk untuk hidup prihatin, dan uang receh yang dikumpulkan tiap hari selama bertahuntahun, Bapak akhirnya membeli sebuah mobil angkot bekas. Akhirnya! Sesuatu yang Bapak impikan sejak lama tercapai (hlm. 103).

Orang tua menjadi model percontohan bagi anak. Setiap orang tua berupaya sebaik mungkin dalam memenuhi kebutuhan keluarga sehingga tanpa lelah kerja keras, misalnya dalam tokoh Bapak yang bekerja dari pagi sampai tengah malam sehingga anak-anaknya jarang untuk bertemu. Begitupun bagi pembaca yang akan merasakan hal yang sama dengan penulis akan meniru yang dijadikan model dalam kehidupannya. Kerja keras bila disertai keuletan, doa, dan usaha akan berdampak tercapai yang diharapkan.

\section{Cinta Tanah Air}

Wujud cinta tanah air juga ditampilkan oleh Bayek saat diterima bekerja di New York. Setiap kembali dari Indonesia, Bayek selalu membawa ole-ole untuk teman-temannya meskipun tidak dijelaskan secara terperinci oleh-oleh yang dimaksud. Bayek mengajarkan pada pembaca untuk mencintai dan bangga untuk memperkenalkan bangsanya kepada warga negara lain seperti yang terlihat pada kutipan di bawah ini.

(9) "Bayek selalu membawa ole-ole untuk semua rekan kerjanya setelah pulang dari Indonesia. Kadang kopernya penuh dengan ole-ole. Ia bangga menunjukkan Indonesia ke rekan-rekannya" (hlm. 212).

Pada kutipan data (9), tampak digambarkan perilaku Bayek yang menunjukkan nilai cinta tanah air. Pemberian oleh-oleh kepada teman-temannya dapat menumbuhkan keingintahuan tentang Indonesia. Hal ini menjadi salah satu cara ajang promosi untuk memperkenalkan, seperti budaya Indonesia bagi warga asing. Melalui kutipan ini, penulis menunjukkan cara menanamkan kebanggaan kepada bangsa bagi anak muda Indonesia.

\section{Jujur}

Nilai kejujuran ditunjukkan oleh $I b u$ k saat mengingatkan Bayek untuk jujur saat akan wawancara dalam kerja. Petuah Ibuk tersebut membawa hawa ketenangan bagi Bayek. Penumbuh- kembangan nilai kejujuran tampak pada kutipan berikut.

(10) "Iya, Yek, Ibuk akan doakan. Yang penting kamu tenang. Yang penting kamu jujur”, balas Ibuk (hlm. 139).

Kutipan data (10) menunjukkan upaya Ibuk membentuk pondasi karakter jujur pada anak-anaknya yang harus dijunjung kapan dan di mana saja. Nilai kejujuran ini menjadi aspek penting dalam pembinaan mental dan karakter anak usia muda saat ini. Melalui novel ini, nilai-nilai tersebut ditanamkan melalui sikap tokoh Ibuk.

\section{Empati}

Nilai empati diperlihatkan Bayek setelah salat Isya, ia membayangkan orang-orang yang terjebak dalam gedung saat pesawat menabrak, orang keluar gedung dengan tubuh penuh debu, orang-orang berhamburan di tangga, ratusan pemadam kebakaran yang berdatangan, orang terjun dari gedung, dan para korban yang dicari keluarganya. Kutipan tentang "New York City berkabung. Sedalam-dalamnya" menunjukkan bahwa tidak hanya orang-orang New York yang berduka mengenai tragedi tersebut tetapi orang-orang di seluruh dunia. Ungkapan sedalam-dalamnya tentu sebagai gambaran bahwa dalam kondisi kedukaan sampai yang paling dalam, hingga tak bisa terlontarkan tuturan seperti tampak pada kutipan di bawah ini.

(11) Air mata Bayek meleleh setelah salat isya. Terlintas bayangan orang-orang yang terjebak dalam gedung saat pesawat menabrak (hlm. 158).

Empati merupakan sikap ikut serta merasakan apa yang dirasakan oleh orang lain. Sama halnya dilakukan oleh tokoh Bayek yang tidak pernah menyangka peristiwa serangan gedung WTC terjadi seperti ditunjukkan pada kutipan (11). Kondisi setelah tragedi tersebut juga dilukiskan oleh Bayek saat keesokan harinya menelusuri Manhattan, kota yang sangat hidup karena padatnya aktivitas di kota tersebut digambarkan berubah menjadi kota melankolis yang sayu, sedih maupun muram disebabkan suasana kedukaan. Situasi yang berbeda tersebut yang dirasakan oleh tokoh Bayek hingga bayangan peristiwa tersebut tidak terlupa dalam pikirannya hingga saat salat pun terbayang dan merasakan hal yang sama tentang kondisi gedung, ling- 
kungan sekitarnya, suasana, korban, dan keluarganya. Melalui kutipan tersebut, pembaca dapat menemukan nilai-nilai empati kepada sesama tanpa memandang perbedaan keyakinan, ras, ataupun suku bangsa.

\section{Gemar Membaca}

Anak-anak Bapak dan Ibuk telah menyukai membaca buku semenjak dini dengan membuat waktu belajar rutin. Bayek juga sering membaca beberapa bacaan baru untuk meningkatkan wawasannya dalam meningkatkan kualitas diri dan kerja. Selain itu, Bayek juga memperlihatkan pentingnya membaca untuk menambah pengetahuan. Kegemaran membaca ditunjukkan pada kutipan berikut.

(12) Bayek juga selalu membelikan buku-buku cerita agar mereka suka membaca (hlm. 201-202).

Melalui kutipan data (12), penulis mengajarkan kepada pembaca tentang pentingnya penumbuhkembangan budaya membaca. Melalui kutipan tersebut digambarkan Bayek yang ingin melakukan pembiasaan membaca pada keluarganya. Tindakan nyata tersebut dilakukan saat Bayek membawakan oleh-oleh buku untuk keponakannya agar tertanam kebiasaan gemar membaca. Makna pendidikan karakter dari kutipan ini adalah keluarga memiliki peranan penting dalam menanamkan kecintaan dalam gemar membaca.

\section{Pembahas an}

Novel Ibuk karya Iwan Setyawan merupakan autobiografi sang pengarang terkait harapan dan perjuangan Bapak dan Ibuk dalam menyekolahkan anak-anaknya sampai perguruan tinggi. Penggunaan sebutan Ibuk disebabkan asal keluarga tersebut dari Jawa. Dalam bahasa Jawa, kata ibu memiliki beberapa varian, yakni ibuk, mak, emak, mbok. Ibuk digambarkan sebagai perempuan Jawa yang tidak menamatkan pendidikan SD sebab sakit saat menjelang ujian akhir kelas VI dan setelah itu Ibuk mengubur harapan untuk dapat menyelesaikan sekolah. Selain itu, Ibuk digambarkan sebagai perempuan yang patuh dan pekerja keras. Ibuk akhirnya hanya tinggal di rumah dan mengurus kelima adiknya. Ibunya Ibuk masih memegang prinsip bahwa perempuan tidak bersekolah tidak apa-apa sebab pada akhirnya ia akan bertugas untuk mengurus rumah tangga dan anak-anak.
Pengarang melalui karya sastranya menyadari pentingnya nilai-nilai yang tersurat maupun tersirat yang dapat diperoleh bagi pembaca. Berdasarkan hasil penelitian, dalam Novel Ibuk karya Iwan Setyawan ditemukan duabelas nilai-nilai pendidikan karakter, yaitu (1) hidup sederhana, (2) tanggung jawab, (3) kasih sayang, (4) berbakti pada orang tua, (5) religius, (6) peduli kebersihan, (7) menghargai prestasi, (8) kerja keras, (9) cinta tanah air, (10) jujur, (11) empati, dan (12) gemar membaca. Duabelas nilai pendidikan karakter tersebut merupakan hasil identifikasi dari delapanbelas nilai pembentuk karakter yang ada dalam pada satuan pendidikan. Oleh karena itu, termuatnya nilai-nilai pendidikan karakter dalam novel tersebut dapat digunakan sebagai pendukung pembelajaran sastra pada jenjang SMA/MA/SMK/SMAK.

Pembelajaran Bahasa Indonesia dapat memberikan kontribusi lebih terkait dengan pendidikan karakter. Materi kurikulum 2013 untuk mata pelajaran bahasa dan sastra Indonesia yang berbasis teks memungkinkan guru untuk menyelipkan materi karakter dalam pembelajaran bahasa Indonesia melalui teks yang dipergunakan dalam pembelajaran. Novel Ibuk merupakan teks sastra dapat dipilih karena bermuatan pendidikan karakter. Nilai-nilai yang ada di dalamnya sesuai dengan nilai karakter dan budaya bangsa yang sedang dikembangkan olek Kementerian Pendidikan dan Kebudayaan.

Pada mata pelajaran Bahasa Indonesia jenjang SMA/MA/SMK/SMAK salah satu teks yang dapat digunakan untuk pengembangan pembelajaran sastra adalah teks novel. Teks novel dikaitkan dengan kompetensi mengidentifikasi, menjelaskan, dan membandingkan unsur instrinsik dan ekstrinsik novel Indonesia maupun novel terjemahan. Selanjutnya, pada pembelajaran kritik sastra novel dapat dilakukan dengan pengenalan genre dan permasalahan karya sastra yang ditelaah melalui tahapan pembuatan sinopsis, dilanjutkan dengan tahapan interpretasi peserta didik terhadap karya sastra yang dianalisis, dan diakhiri dengan penilaian terkait kelebihan serta kekurangan karya sastra yang diulas. Pemilihan tokoh, permasalahan, bahasa, dan genre sastra dapat memengaruhi menjadi topik kajian pembelajaran sastra. Karakteristik tokoh Ibuk dan permasalahan tentang keluarga yang dimiliki dalam novel $I b u k$ tepat digunakan untuk pembelajaran sastra di jenjang SMA/MA/SMK/SMAK. 


\section{SIMPULAN}

Berdasarkan hasil penelitian, ditemukan dua belas nilai-nilai pendidikan karakter dalam novel Ibuk, meliputi (1) hidup sederhana, (2) tanggung jawab, (3) kasih sayang, (4) berbakti pada orang tua, (5) religius, (6) peduli, (7) menghargai prestasi, (8) kerja keras, (9) cinta tanah air, (10) jujur, (11) empati, dan (12) gemar membaca. Keteladanan dalam novel Ibuk yang ditunjukkan melalui nilai-nilai yang ada di dalamnya dapat dijadikan sebagai salah satu bahan ajar pembelajaran sastra dalam materi teks novel dan teks kritik sastra pada jenjang SMA/MA/SMK/ SMAK.

Tokoh ibu dalam novel Ibuk digambarkan sebagai perempuan yang sederhana, rajin, cekatan, sayang terhadap keluarga, kerja keras, dan memiliki harapan anak-anaknya dapat bersekolah hingga perguruan tinggi. Melalui tokoh Ibuk digambarkan sebagai tokoh yang berhasil merealisasikan perannya sebagai istri, pendidik bagi

\section{DAFTAR PUSTAKA}

Armis, dkk. 2015. Representasi Tokoh Lisa dalam Novel Bunda Lisa Karya Jombang Santani Khairen: Kajian Psikologi Wanita. Jurnal Publika Budaya, 1 (3): 34-45.

Djajanegara, S. 2003. Kritik Sastra Feminis. Jakarta: Gramedia Pustaka Utama.

Endraswara, S. 2008. Metodologi Penelitian Sastra. Yogyakarta: MedPress.

Hayati, Y. 2014. Representasi Ibu dalam Sastra Anak di Indonesia: Studi Kasus Terhadap Sastra Anak Karya Anak Periode 2000-an. Jurnal Humanus, (1): 45-50.

Kementerian Pendidikan Nasional. 2010. Bahan Pelatihan Penguatan Metodologi Pembelajaran Berdasarkan Nilai-nilai Budaya untuk Membentuk Daya Saing dan Karakter Bangsa. Jakarta: Kementerian Pendidiakn Nasional. anak-anaknya, dan pengelola rumah tangga. Keunggulan sikap Ibuk meskipun tidak menamatkan sekolah dan dengan keterbatasan ekonomi tetapi tidak menyurutkan angan untuk anak-anaknya memiliki kehidupan yang lebih baik dengan berpendidikan. Karakter demkian merupakan nilai pendidikan yang direpresentasikan melalui novel dan dapat menjadi model bagi Ibu (orang tua masa kini) dalam mendidik anak-anaknya. Bagi pembaca perempuan, sosok ibu menjadi contoh dalam memerankan posisi ibu yang hidup dengan cinta kasih dan menjadi pilar pendidikan keluarga.

\section{UCAPAN TERIMA KASIH}

Penulis menyampaikan ucapan terima kasih kepada mitra bestari (reviewers) yang telah memberikan saran, kritik, dan rekomendasi perbaikan artikel ini.

Mansur, R. H. 2014. Implementasi Pendidikan Karakter di Satuan Pendidikan. Jurnal LPMP SulSel, 1(1): 1-13.

Pradopo, R. D. 2005. Beberapa Teori Sastra, Metode, dan Kritik. Yogyakarta: Pustaka Pelajar.

Ratna, N. K. 2004. Teori, Metode, dan Teknik Penelitian Sastra. Yogyakarta: Pustaka Pelajar.

Setiadi, Elly. M. 2006. Ilmu Sosial dan Budaya Dasar. Jakarta: Kencana.

Setyawan, I. 2012. Ibuk. Jakarta: Gramedia.

Soharahab, V. Z. dan Marwanti. 2016. Nilai-Nilai Pendidikan dalam Novel Sabtu Bersama Bapak Karya Adhitya Mulya. Jurnal Bastra, 3 (3): 1-16.

Sudjiman, P. 1998. Bunga Rampai Stilistika. Jakarta: Pustaka Jaya. 